following features: a special legal regime, according to which the property right of internally displaced persons can be recognized as an independent type of property; it is the property, when there is a split of legal and actual possession of an item; the presence of the following characteristics of the property right of internally displaced persons: the split of legal and actual ownership of property objects, the presence of a direct relationship with non-property rights of a person (on physical and social being of a person), the actual limitation of peaceful possession of property, restrictions on the use of all civil and legal means for protecting the property right.

Keywords: internally displaced persons, property right, possession, object of ownership, migration, terrorism, displace.

DOI: $10.33766 / 2524-0323.91 .225-238$

УДК 349.6

В. М. Комарницький, доктор юридичних наук, професор, провідний науковий співробітник науково-дослідної лабораторіі з проблем попередження, припинення та розслідування злочинів територіальними органами

Національної поліції України Луганського державного університету внутрішніх справ імені Е. О.Дідоренка

(м. Сєвєродонецьк, Україна) e-mail:mail@lduvs.edu.ua iD ttps://orcid.org/0000-0003-1510-2395 M. I. Срофеєв, кандидат юридичних наук, науковий співробітник науково-дослідної лабораторіі 3 проблем попередження, припинення та розслідування злочинів територіальними органами Національної поліції України

Луганського державного університету внутрішніх справ імені Е. О. Дідоренка (м.Сєвєродонецьк, Україна) e-mail:erofeevnikolay50@gmail.com iD ttps://orcid.org/0000-0001-7679-7341

\title{
ПРАВОВІ ПИТАННЯ ВЗАСМОДІЇ ПРАВООХОРОННИХ ОРГАНІВ ІЗ ГРОМАДСЬКІСТЮ ЩОДО ЗАБЕЗПЕЧЕННЯ ОХОРОНИ ДОВКІЛЛЯ
}

У статті розглянуто проблеми щодо прав громадян, громадських об'єднань у сфері охорони довкілля; основні форми реалізації цих прав у процесі взаємодії з правоохоронними органами. Акцентовано увагу на недоліках (прогалинах) законодавства в регулюванні відносин, що вникають між громадськістю та правоохоронними органами при здійсненні екологічного контролю, притягненні до юридичної відповідальності порушників екологічного законодавства, судовому захисті екологічних інтересів суспільства. Також обгрунтовано рекомендації та пропозищії щодо усунення цих законодавчих недоліків (прогалин).

Ключові слова: громадськість, правоохоронні органи, взаємодія, охорона довкілля, екологічне законодавство.

(C) Комарницький В. М., Єрофеєв М. I., 2020 
Постановка проблеми. Успіх у боротьбі з екологічними правопорушеннями в значній мірі залежить від належної організації взаємодії (координації дій) громадськості та правоохоронних органів, які до неї залучені. Це дозволяє своєчасно реагувати на вчинення правопорушень у сфері природокористування, охорони довкілля, оперативно виявляти осіб, які скоӥли такі правопорушення, та притягувати їх до юридичної відповідальності. Така взаємодія здійснюється не стихійно, а згідно з вимогами законодавства, що визначають права та обов'язки відповідних суб'єктів, форми їхньої взаємодії, заходи протидії екологічним правопорушенням, які вони можуть здійснювати. Це законодавство, як і в цілому питання взаємодії правоохоронних органів та громадськості в даній сфері, стало в останні роки предметом спеціальних досліджень, спрямованих на висвітлення правових та організаційних проблем зазначеної взаємодіiі. Дана стаття продовжує џі дослідження, акцентуючи увагу на недоліках відповідного законодавства, які в ньому лишилися й потребують усунення.

Аналіз останніх досліджень і публікацій. Питання взаємодії правоохоронних органів та громадськості у сфері охорони довкілля в тій чи іншій мірі досліджувалося в роботах Б. Гамалюка, В. Борейка, В. Бредіхіної, І. Казанчука, В. Колпакова, М. Краснової, В. Ксендзюка, Т. Кухара, А. Ланкевича, Ю. Назара, О. Овчаренка, М. Слівки, С. Стороженка, В. Тюна, О. Хіміча, К. Ялового та ін. Утім, незважаючи на дослідження науковців, питання взаємодії правоохоронних органів та громадськості у сфері охорони довкілля потребує подальшого вивчення з метою опрацювання оптимальної моделі зазначеної взаємодії та ії законодавчого забезпечення.

Формулювання цілей. Метою статті є аналіз правового забезпечення взаємодії правоохоронних органів і громадськості у сфері охорони довкілля та обгрунтування пропозищій щодо його удосконалення.

Виклад основного матеріалу. Природоохоронна діяльність органів держави є важливим елементом забезпечення конституційного права громадян на безпечне для життя і здоров'я довкілля (ст. 50 Конституції України). Але громадяни не є лише спостерігачами розв'язання державою екологічних проблем і стороною, котра пасивно очікує позитивних екологічних наслідків реалізації державних та місцевих програм із охорони довкілля й здійснення інших природоохоронних заходів; їм (громадянам) надані права, які дозволяють долучитися до вирішення нагальних проблем охорони довкілля, що мають місце в країні та в їі окремих регіонах.

Зокрема, згідно зі ст. 9 Закону України «Про охорону навколишнього природного середовища», кожний громадянин України має право на: участь в обговоренні та внесення пропозищій до проектів нормативно-правових актів, матеріалів щодо розміщення, будівнищтва і реконструкції об'єктів, які можуть негативно впливати на стан навколишнього природного середовища, внесення пропозищій до органів державної влади та органів місцевого самоврядування, юридичних осіб, що беруть участь у прийнятті рішень із цих питань; участь у розробці та здійсненні заходів щодо охорони навколишнього природного середовища, ращіонального і комплексного використання природних ресурсів; об'єднання в громадські природоохоронні формування; вільний доступ до інформації про стан навколишнього природного середовища (екологічна інформація) та вільне отримання, використання, поширення та зберігання такої інформації, за винятком обмежень, встановлених законом; участь у 
громадських обговореннях із питань впливу планованої діяльності на довкілля; подання до суду позовів до державних органів, підприємств, установ, організацій і громадян про відшкодування шкоди, заподіяної їх здоров'ю та майну внаслідок негативного впливу на навколишнє природне середовище; оскарження в судовому порядку рішень, дій або бездіяльності органів державної влади, органів місцевого самоврядування, їх посадових осіб щодо порушення екологічних прав громадян у порядку, передбаченому законом тощо.

Відповідні повноваження в даній сфері надані й громадським природоохоронним організаціям, які, згідно зі ст. 21 Закону України «Про охорону навколишнього природного середовища», мають право: брати участь у розробці планів, програм, пов'язаних із охороною навколишнього природного середовища, розробляти й пропагувати свої екологічні програми; брати участь у проведенні центральним органом виконавчої влади, що реалізує державну політику із здійснення державного нагляду (контролю) у сфері охорони навколишнього природного середовища, ращіонального використання, відтворення й охорони природних ресурсів, перевірок виконання підприємствами, установами та організаціями природоохоронних планів і заходів; виступати з ініңіативою проведення всеукраїнського і місцевих референдумів із питань, пов'язаних із охороною навколишнього природного середовища, використанням природних ресурсів та забезпеченням екологічної безпеки; вносити до відповідних органів пропозищії про організацію територій та об'єктів природно-заповідного фонду; подавати до суду позови про відшкодування шкоди, заподіяної внаслідок порушення законодавства про охорону навколишнього природного середовища, у тому числі здоров'ю громадян і майну громадських організацій; оскаржувати в установленому законом порядку рішення про відмову чи несвоєчасне надання за запитом екологічної інформації або неправомірне відхилення запиту та його неповне задоволення тощо.

Реалізація громадянами та громадськими природоохоронними організаціями наданих їм екологічних прав передбачає тісний контакт, взаємодію з органами держави. Це дозволяє останнім почути громадську думку з того чи іншого питання охорони довкілля, забезпечення екологічної безпеки та врахувати її при прийнятті екологічно значущих рішень, отримати зацікавлених (екологічно мотивованих) помічників при організації здійснення заходів екологічної спрямованості, а громадянам та громадським природоохоронним організаціям - виходити 3 природоохоронними ініціативами до уповноважених державних органів і в разі потреби захищати суспіљьні екологічні інтереси в суді.

Серед органів держави, з якими мають взаємодіяти окремі громадяни та їх громадські об'єднання, особливе місце посідають правоохоронні органи (суд, органи внутрішніх справ, державна екологічна інспекція тощо), діяльність яких спрямована на забезпечення законності й правопорядку у сфері охорони природи, забезпечення екологічної безпеки, природокористування (включаючи захист екологічних прав та інтересів громадян і суспільства, попередження та припинення екологічних правопорушень, застосування державного примусу до осіб, які порушили правові екологічні вимоги та правила). Важливим напрямком такої взаємодії є здійснення контролю за додержанням суб'єктами екологічних відносин вимог законодавства з охорони на- 
вколишнього природного середовища, адже такий контроль закладає основу для всебічного врахування інтересів суспільства та держави при формуванні й реалізащіі екологічної політики на державному та місцевому рівнях. Він (контроль у даній сфері), зокрема, створює умови для запобігання реалізації проектів господарської діяльності, що є екологічно небезпечною; зупинення такої діяльності, у разі коли вона здійснюється з порушеннями екологічних нормативів та завдає шкоди довкіллю; підтримання режиму законності у сфері природокористування. Важливо, що екологічний контроль, у якому бере участь громадськість, дозволяє не тільки виявити відхилення від екологічних приписів законодавства при прийнятті управлінських рішень із питань економічного та соціального розвитку, а й оперативно оскаржити їх, поставити питання про притягнення до відповідальності належних осіб.

Базовою 3 питань громадського контролю в галузі охорони довкілля є ст. 36 Закону України «Про охорону навколишнього природного середовища», яка встановила, що «громадський контроль у галузі охорони навколишнього природного середовищя здійснюється громадськими інспекторами з охорони довкіля згідно з Положенням, яке затверджується центральним органом виконавчої влади, що забезпечує фрормування державної політики у сорері охорони навколишнъого природного середовища».

У цій статті чітко прослідковується ідея взаємодії такого інституту громадського суспільства як громадська інспектура з відповідними державними органами. Зокрема, встановлено, що громадські інспектори з охорони довкілля спільно з пращівниками органів державного контролю беруть участь у проведенні рейдів та перевірок додержання підприємствами, установами, організаціями та громадянами законодавства про охорону навколишнього природного середовища, додержання норм екологічної безпеки та використання природних ресурсів; проводять перевірки і складають протоколи про правопорушення законодавства про охорону навколишнього природного середовища і подають їх органам державного контролю в галузі охорони навколишнього природного середовища та правоохоронним органам для притягнення винних до відповідальності; подають допомогу органам державного контролю в галузі охорони навколишнього природного середовища в діяльності по запобіганню екологічним правопорушенням.

Чинна редакція ст. 36 Закону України «Про охорону навколишнього природного середовища» ставить формування інституту громадських інспекторів із охорони довкілля в залежність від державних природоохоронних органів. Проте так було не завжди. До 1999 р. громадську інспектуру мали право створювати не лише підрозділи Держекоінспекції, а й громадські природоохоронні формування (див. пункт 1 Положення про громадський контроль у галузі охорони навколишнього природного середовища: наказ Мінприроди №81 від 04.08.1994 р. (наказ утратив чинність на підставі наказу Мінекобезпеки №150 від 05.07.1999 р.) [1], які, відповідно, мали й білыше самостійності в організації перевірок дотримання вимог екологічного законодавства та можливостей впливати на бездіяльність державних органів у даній сфері [2]. С сенс повернутися до колишньої практики та надати громадським природоохоронним формуванням право створювати громадську екологічну інспектуру. Причому слід відмовитися від відомчої нормотворчості із зазначеного питання, яка ставить громадську екологічну інспектуру в залежність від державних контролюю- 
чих органів, і покласти на Кабінет Міністрів України прийняття положення про громадську екологічну інспектуру. Відповідні зміни мають бути внесені до ст. 36 Закону України «Про охорону навколишнього природного середовища».

У контексті вищезазначеного питання не можна не звернути увагу на те, що в Законі України «Про охорону навколишнього природного середовища» не згадується взаємодія громадських природоохоронних формувань, громадської екологічної інспектури з іншими громадськими формуваннями в здійсненні заходів щодо охорони довкілля, контролю з додержанням еколого-правових вимог та правил. Утім, така взаємодія має важливе значення для об'єднання сил та можливостей різноманітних громадських формувань з метою розв'язання екологічних проблем. Цей момент враховано в Законі України «Про участь громадян в охороні громадського порядку і державного кордону», який встановив, що для виконання завдань, визначених у ньому (зокрема, надання допомоги органам Національної поліції в забезпеченні громадського порядку і громадської безпеки, запобіганні адміністративним проступкам і злочинам тощо, - ст. 9), громадські формування з охорони громадського порядку і державного кордону та їх члени мають право взаємодіяти з іншими органами громадської самодіяльності, що беруть участь у заходах, спрямованих на охорону природи і пам'яток історії та культури, надання допомоги в боротьбі із порушеннями правил у сфері благоустрою території міст, інших населених пунктів тощо (пункт 4 ст. 10). Кореспондуючи цим приписам положення, що фіксують право громадських природоохоронних організацій на організащію взаємодії з іншими громадськими формуваннями при здійсненні заходів боротьби з екологічними правопорушеннями, слід включити й до статті 21 «Повноваження громадських організацій у галузі охорони навколишнього природного середовища» Закону України «Про охорону навколишнього природного середовища».

Характер контрольної діяльності громадськості у сфері охорони довкілля потребує від них також налагодження взаємодії з поліцією. Таке, зокрема, може мати місце у випадках, коли громадські природоохоронні формування організуютьпроведення заходів боротьби з незаконною вирубкою лісу, незаконним продажем ранньоквітучих рослин, новорічних ялинок, із рибним і мисливським браконьєрством, іншими екологічними правопорушеннями. Підтримка поліщії в таких випадках посилює ефективність відповідних заходів, гарантує безпеку учасників операцій боротьбиз незаконним природокористуванням, дозволяє оперативно встановити особистість порушника на місці, здійснити у відповідних випадках адміністративне затримання порушника законодавства про охорону і використання тваринного світу, забезпечити швидке перевезення учасників природоохоронних груп у визначені місця тощо [3].

Співпраця поліщії з відповідними громадськими формуваннями здійснюеться в руслі приписів Закону України «Про Національну поліцію» від 02.07.2015 р. № 580VIII, що визначають завдання поліщії у сфері забезпечення публічної безпеки і порядку та правові засади ії «взаємодії з населенням, територіальними громадами та громадськими об'єднаннями на засадах партнерства» (статті 2, 11), які поширюються й на природоохоронну сферу суспільного життя. У юридичній літературі доводиться потреба в уточненні в Законі України «Про Національну поліцію» екологічних аспектів діяльності поліції [4; 5; 6]. 3 ними варто погодитися, зокрема, у частині, що стосується включення до ч. 1 статті 11 
цього Закону припису, який безпосередньо буде визначати спрямованість взаємодії поліції з населенням, територіальними громадами та громадськими об'єднаннями на задоволення їх конкретних потреб, зокрема, у сфері охорони довкілля. Водночас, слід й у ст. 21 Закону України «Про охорону навколишнього природного середовища» передбачати положення, за яким громадські природоохоронні організації спільно 3 поліцейськими мають право вживати заходи щодо запобігання та припинення адміністративних правопорушень і злочинів у галузі охорони довкілля. Це дозволить відбити в законі реальну природоохоронну практику поліції, засновану на взаємодії 3 відповідними інститутами громадського суспільства.

Нового імпульсу взаємодії поліщії з громадськими природоохоронними має надати позитивне вирішення питання про реформування системи державного екологічного контролю в Україні, що є неефективним, шляхом створення Екологічної поліції. Одразу слід зазначити, що з цього приводу існують різні міркування. Висловлюється, зокрема, думка, що, замість утворення Екологічної поліції, має реформуватися екологічна інспекція за моделлю реформи поліції [7]. Утім, суспільна думка все більше схиляється до підтримки створення в Україні саме Екологічної поліції. Зокрема, в електронній петищії про створення такої поліщії, що була розміщена на сайті офіційного інтернет-представництва Президента України [8], зазначалося, що «Країні потрібен контрольний механізм, що зможе не лише фіксувати правопорушення, але й вчасно їм запобігати, об'єднуючи в роботі єдиного органу функції здійснення оперативно-розшукової, кримінально-процесуальної, контрольної, виконавчої, охоронної функцій. Саме такі функції може виконувати екологічна поліція, маючи конкретні завдання щодо дотримання відповідними суб'єктами своїх обов'язків у сфері охорони природи та користування ії багатствами». Слід підтримати таку пропозищію й приєднатися в перспективі до країн, де така поліщія утворена та успішно пращює. Ідеться про Бразилію, де екополіція перебуває в структурі МВС, Ізраїґь, у якому така поліція підпорядкована Міністерству екологіі, США, де екополіція функціонує як на рівні штатів, так і на рівні міст. Також екополіція утворена в Італії, де має назву Командування підрозділів карабінерів по лісовому господарству, захисту навколишнього середовища та агропродовольчому захисту [9].

Важливий аспект взаємодії громадськості та правоохоронних органів складає боротьба із корупщією. Форми такої взаємодії, у тому числі і в екологічній сфері, визначені в Законі України «Про запобігання корупщії, згідно з яким (ст. 21), зокрема, громадські об'єднання, окремі громадяни мають право: «повідомляти про виявлені факти вчинення корупщйних або пов'язаних із корупцією правопорушень, реальний, потенщійний конфлікт інтересів спеціально уповноваженим суб'єктам у сфері протидії корупщї, Нащіональному агентству, керівнищтву чи іншим представникам органу, підприємства, установи чи організації, у яких були вчинені ці правопорушення, або в працівників, у яких наявний конфлікт інтересів, а також громадськості» тощо. В екологічній сфері корупція може мати різні прояви. Приміром, екологічні інспектори під час перевірки могли «не помітити», що на об'єкті перевищені показники викидів забруднюючих речовин у довкілля, порушені інші природоохоронні правила, або ж брати кошти за пропуск через державний кордон речовин, що не відповідають нормам екологічного контролю, тощо [10]. 
3 метою посилення ефективності боротьби з корупщійними проявами у даній сфері в останні роки тут почали запроваджуватися різноманітні антикорупщійні заходи правового та організаційного характеру [11]. Серед них слід виділити ті, що спрямовані на удосконалення юридичної відповідальності за відповідні правопорушення у сфері охорони довкілля. Ідеться про встановлення адміністративної відповідальності за порушення законодавства у сфері оцінки впливу на довкілля (частина перша ст. 172-9-2 КУпАП, які включені до складу адміністративний правопорушень, пов'язаних із корупцією (Гл. 13-А КУпАП). До цієї групи правопорушень включені: порушення встановленої законодавством процедури та строків здійснення оцінки впливу на довкілля, втручання в підготовку та надання висновку з оцінки впливу на довкілля чи рішення про врахування результатів оцінки транскордонного впливу на довкілля, відмова уповноваженим законом територіальним органом, уповноваженим законом центральним органом виконавчої влади у видачі висновку з оцінки впливу на довкілля з підстав, не встановлених законом.

Для громадськості встановлення складу правопорушень у сфері оцінки впливу на довкілля з чіткими кваліфікуючими ознаками має те значення, що вона отримує конкретні орієнтири для визначення (перевірки) відповідності дій суб'єктів, що залучені до оцінки впливу на довкілля, вимогам законодавства, що регулює ії здійснення, а відтак полегшується доведення наявності конкретного складу правопорушення в цих діях, створюються умови для білыш оперативного реагування на відповідні правопорушення, повідомлення про них уповноваженим органам.

Слід зауважити, що увага до корупщійних аспектів ощінки впливу на довкілля $є$ невипадковою. Остання сьогодні відіграє ключову роль у запобіганні появі в Україні нових екологічно небезпечних джерел, адже є обов'язковою для планованої господарської діяльності (проектів виробничих об'єктів тощо), яка може чинити небезпечний вплив на довкілля. Без позитивного висновку зазначеної ощінки здійснення планованої господарської діяльності заборонено. Обов'язковими є врахування висновків оцінки впливу на довкілля при прийнятті рішення про провадження планованої господарської діяльності та дотримання екологічних умов, визначених у зазначених висновках, під час провадження господарської діяльності, експлуатації об'єктів. Закон України «Про оцінку впливу на довкілля» надає громадськості можливість контролювати процес оцінки впливу на довкілля на всіх його стадіях та відповідним чином реагувати на порушення порядку їі (оцінки) здійснення.

Якщо адміністративно-правова база боротьби з корущційними та іншими порушеннями законодавства про оцінку впливу на довкілля в цілому відповідає потребам природоохоронної практики органів державного контролю та громадськості, то кримінально-правовий аспект цієї боротьби потребує удосконалення.

Зокрема, правопорушення у сфері оцінки впливу на довкілля, які зараз включені до ст. 236 КК України, слід виокремити в окрему статтю [12]. Вона має отримати назву «Порушення вимог законодавства про оцінку впливу на довкілля» і містити склади правопорушень, які у відповідних випадках (спричинили загибель людей, екологічне забруднення значних територій або інші тяжкі наслідки можуть кваліфікуватися, як злочини. Правопорушення з такими складами передбачені в ст. 15 Закону України «Про оцінку впливу на довкілля» і включають наступні: 1) неврахування у встановле- 
ному порядку результатів оцінки впливу на довкілля при прийнятті рішення про провадження планованої діяльності; 2) підготовка завідомо неправдивого висновку з ощінки впливу на довкілля; 3) провадження планованої діяльності, яка підлягає оцінщі впливу на довкілля, без здійснення такої оцінки та отримання рішення про провадження планованої діяльності; 4) недотримання під час провадження господарської діяльності, експлуатації об'єктів, інших втручань у природне середовище й ландшафти, у тому числі з видобуванням корисних копалин, використанням техногенних родовищ корисних копалин, екологічних умов, визначених у висновку з оцінки впливу на довкілля, рішенні про провадження планованої діяльності.

Ці склади правопорушень дозволяють сфокусувати увагу правоохоронних органів та громадськості на найбілыш небезпечних злочинах у сфері оцінки впливу на довкілля. Причому перші два правопорушення (неврахування у встановленому порядку результатів ощінки впливу на довкілля при прийнятті рішення про провадження планованої діяльності; підготовка завідомо неправдивого висновку з оцінки впливу на довкілля), що можуть бути скоєні лише шляхом зловживання службовим становищем, варто включити до переліку корупщйних злочинів, які перераховані в примітці до ст. 45 КК України, адже вони є не менш суспільно небезпечні, ніж ті, що передбачені в чинній редакції примітки до ст. 45 КК України (корупційні злочини у сфері обігу зброї, бойових припасів, вибухових речовин, радіоактивних матеріалів, військового майна, наркотичних засобів, психотропних речовин, документів, штампів, печаток - статті 262, 308, 312, 313, 320, 357, 410 КК України).

Для захисту екологічних інтересів суспільства важливою є взаємодія громадських природоохоронних об'єднань із судами з питань відшкодування шкоди, заподіяної внаслідок порушення законодавства про охорону навколишнього природного середовища, та припинення діяльності, що призводить до нищення, псування, забруднення довкілля. Тут звертає на себе увагу наступне. Якщо право громадських природоохоронних об'єднань подавати до суду позови про відшкодування шкоди, заподіяної внаслідок порушення екологічного законодавства, чітко зафіксовано в Законі України «Про охорону навколишнього природного середовища» (пункт «Ж» частини першої ст. 21), що дозволяє без перепон їм користуватися, то право громадських об'єднань на звернення до суду про припинення екологічно небезпечної діяльності в ньому не зафіксовано. Прямо таке право не передбачено й іншими законодавчими актами. Приміром, Цивільний кодекс України містить припис, який зумовлює звужене розуміння кола осіб, котрі мають право на відповідне звернення до суду. Він установив, що «Діяльність фізичної та юридичної особи, що призводить до нищення, псування, забруднення довкілля, є незаконною. Кожен має право вимагати припинення такої діяльності. Діяльність фізичної та юридичної особи, яка завдає шкоди довкіллю, може бути припинена за рішенням суду». Згідно з рішеннням Конституційного Суду України, під «кожним» слід розуміти громадянина України, іноземця, особи без громадянства [13]. У цьому переліку не названі громадські природоохоронні об'єднання, що заважала останнім брати активну участь у судовому захисті екологічних інтересів суспільства. На це звернула увагу Велика Палата Верховного Суду Українипри розгляді справи за позовом МБО «Екологія-Право-Людина» до ТОВ «Аквадельф» про заборону діяльності дельфінарію (справа № 910/8122/17, провадження № 12-186гс18). У Постанові від 11 грудня 2018 року [14] Велика Палата зазначила, що, 
відмовляючи в позові щодо цієї справи, суди застосували обмежене тлумачення чинного законодавства, частиною якого є Орхуська конвенщія [15], проігнорувавши, що право на захист порушеного конституційного права на безпечне довкілля належить кожному та може реалізовуватися як особисто, так і шляхом участі представника громадськості, яким у цьому випадку є МБО «Екологія-Право-Людина». 3 огляду на зазначене, слід уточнити редакцію пункту «ж» частини першої ст. 21 Закону України «Про охорону навколишнього природного середовища», доповнивши його положенням, за яким громадські природоохоронні об'єднання матимуть право подавати позов до суду «про припинення діяльності, що завдає шкоди навколишньому природному середовищу». Також зазначене положення слід включити й до ст. 9 Закону України «Про охорону навколишнього природного середовища». Це дозволить усунути прогалину у визначенні в ній екологічних прав громадян.

Висновки. Ефективність взаємодії громадян, їх об'єднань із правоохоронними органами з питань охорони довкілля безпосередньо залежить від чіткості та повноти законодавчого забезпечення природоохоронних повноважень цих суб'єктів. Оцінюючи з цієї точки зору законодавство, можна констатувати наявність у ньому прогалин та окремих недоліків, які слід усунути.

1. Відповідних коригувань, зокрема, потребує Закон України «Про охорону навколишнього природного середовища»:

1) у ст. 36 слід: а) передбачити право громадських природоохоронних об'єднань створювати громадську екологічну інспектуру, що надасть їм білышої самостійності в організації перевірок дотримання вимог екологічного законодавства та білыших можливостей впливати на діяльність (бездіяльність) державних органів у даній сфері; б) покласти на Кабінет Міністрів України прийняття положення про громадську екологічну інспектуру, яка дозволить позбавитися відомчої нормотворчості із зазначеного питання, що ставить громадську екологічну інспектуру в залежність від державних контролюючих органів;

2) статтю 9 та пункт «ж» частини першої ст. 21 слід доповнити положеннями, котрі надають, відповідно, громадянам та громадським природоохоронним об'єднанням право подавати позов до суду про припинення діяльності, що завдає шкоди навколишньому природному середовищу. Це дозволить усунути прогалину у визначенні в Законі України «Про охорону навколишнього природного середовища» екологічних прав громадян та громадських природоохоронних об'єднань, поліпшить законодавчу базу взаємодії громадськості із судовими органами у вирішенні відповідних питань.

3) у ст. 21 слід також передбачати: а) положення, за яким громадські природоохоронні об'єднання мають право вживати спільно з поліцейськими заходів до запобігання та припинення адміністративних правопорушень та злочинів у галузі охорони довкілля. Це дозволить відбити в Законі України «Про охорону навколишньього природного середовища» реальну природоохоронну практику поліщіі, засновану на взаємодії з відповідними інститутами громадського суспільства; б) право громадських природоохоронних об'єднань на організацію взаємодії з іншими громадськими формуваннями при здійсненні заходів боротьби із екологічними правопорушеннями. 
Це підкресліть важливість об'єднання сил та можливостей різноманітних громадських формувань, у тому числі тих, що діють під егідою правоохоронних органів (громадські формування з охорони громадського порядку й державного кордону).

2. У частині першій ст. 11 Закону України «Про Національну поліцію» доцільно конкретизувати потреби (включивши до них, зокрема, охорону довкілля) населення, територіальних громад та громадських об'єднань, на задоволення яких спрямована діяльність поліції. Цепосилить інформаційно-регламентуюче навантаження зазначеної статті.

3. Правопорушення у сфері оцінки впливу на довкілля, які зараз включені до ст. 236 КК України, слід виділити в окрему статтю, яка має отримати назву «Порушення вимог законодавства про оцінку впливу на довкілля» і включати склади правопорушень, які у відповідних випадках можуть кваліфікуватися, як злочини. Правопорушення з такими складами передбачені в ст. 15 Закону України «Про оцінку впливу на довкілля». Серед них є такі, що можуть бути скоєні лише шляхом зловживання службовим становищем (неврахування у встановленому порядку результатів ощінки впливу на довкілля при прийнятті рішення про провадження планованої діяльності; підготовка завідомо неправдивого висновку з ощінки впливу на довкілля). Їх варто буде включити до переліку корупційних злочинів, які перераховані в примітці до ст. 45 КК України. Для громадськості встановлення складу злочинів у сфері оцінки впливу на довкілля з чіткими кваліфікуючими ознаками має те значення, що вона отримує конкретні орієнтири для визначення (перевірки) відповідності дій суб'єктів, які залучені до оцінки впливу на довкілля, вимогам законодавства, що регулює їі здійснення.

4. Позитивне вирішення питання про утворення в Україні Екологічної поліції 3 урахуванням досвіду країни, де така поліщія функціонує, дозволить громадськості отримати потужного партнера в боротьби з екологічними правопорушеннями.

\section{Використані джерела:}

1. Положення про громадський контроль у галузі охорони навколишнього природного середовища: наказ Мінприроди №81 від 04.08.1994 р. (наказ втратив чинність на підставі наказу Мінекобезпеки № 150 від 05.07.1999 p.). URL:https:/ / zakon.rada.gov.ua/laws/show/z0229-94.

2. Малишева Н. Р., Єрофеєв М. І. Науково-практичний коментар до Закону Украӥни «Про охорону навколишнього природного середовища». Харків: Право, 2017. С. 147-149.

3. Берзіна С. В. Громадський екологічний контроль: посіб. для громадських інспекторів з охорони довкілля / С. В. Берзіна, В. С. Борейко, Г. С. Бузан; за заг. ред. І. О. Яковлєва. К.: Інститут екологічного управління та збалансованого природокористування, 2017.150 c.

4. Комарнищький В. М., Срофеєв М. І. Поліцейське забезпечення екологічної безпеки: правові питання/ / Вісник Луганського державного університету внутрішніх справ імені Е. О. Дідоренка. 2017. Вип. 1. С. 150-157.

5. Казанчук I. Д. Компетенщія органів Нащіональної поліщії України щодо охорони навколишнього природного середовища та екологічної безпеки в інтеграційних умовах / / Наме npabo, № 1. 2017. C. 54-61. URL:http:/ / nashe-pravo.unesco-socio.in.ua/?s=\%E2\%84\%961+2017.

6. Гамалюк Б. М. Діяльність Національної поліції України з дотримання державних екологічних гарантій: теоретико-методологічний аспект / / Збірник наукових праць Львівського держаВного університету внутрішніх справ. Серія юридична. Випуск 3. 2016. С. 150-161. URL:http:// www.lvduvs.edu.ua/seriya-ur?limitstart $=0$ ).

7. Овчаренко О. «Реформа екологічної інспекції повинна відбутись за моделлю реформиполімії,-Остап Семерак»/О. Овчаренко, Т. Кухар / / Льъівський портал: Iнтернет-видання. 
2016/. URL:http://portal.lviv.ua/news/2016/05/28/reforma-ekologichnoyi-inspektsiyi-povinnavidbutis-za-modellyu-reformi-politsiyi-ostap-semerak.

8. Створення екологічної поліції (екополіпії) для попередження та припинення правопорушень у сфері охорони довкілля. Автор (ініціатор): Яловий Костянтин Володимирович. Дата оприлюднення: 28 квітня 2020 р. № 22/094470-еп/ / Електронні петииії. Офіиційне Інтернет-представництво Президента України. URL:https:/ / petition.president.gov.ua/petition/94470).

9. Яловий К. Україні потрібна екологічна поліція/Украӥнська правда. 27.04 .20202 р. URL:https://www.pravda.com.ua/columns/2020/04/27/7249509.

10. Карнаух Л. Екологічна реформа: як усунути корупшійні ризики при зміні системи?/LexInform. Юридичні новини України. URL:https:/ / lexinform.com.ua/v-ukraini/ekologichnareforma-yak-usunuty-koruptsïni-ryzyky-pry-zmini-systemy/.

11. Комарнищький В. М., Срофеєв М. І. Правові та організащійні аспекти антикорупщійної політики в галузі охорони довкілля// Особливості правового регулювання екологічних, земельних, аграрних, природоресурсних відносин в умовах глобалізації. Збірник матеріалів Всеукраӥнської науково-практичної конфееренції (м. Івано-Франківськ, 20-22 вересня 2019 р.) Івано-Франківськ - м. Яремче: Прикарпат. нац. ун-т ім. Василя Стефаника, 2019. С. 70-74.

12. Срофеєв M. I. Кримінальна віпповідальність за правопорушення у сфері оцінки впливу на довкілля: питання удосконалення законодавчого регулювання/ / Вісник Луганського державного університету Внуттінніх справ імені Е. О. Дідоренка. 2020. Вип.1 (89). С. 71-79.

13. Рішення Конституційного Суду Украӥни у справі за конституційним зверненням громадянки Дзюби Галини Павлівни щодо офіційного тлумачення частини другої статті 55 Конституції України та статті 248-2 Цивіљьного процесуального кодексу України (справа громадянки Дзюби Г. П. щодо права на оскарження в суді неправомірних дій посадової особи) від 25.11.1997 p. URL:https:/ /zakon.rada.gov.ua/laws/show/v006p710-97.

14. Постанова Великої Палати Верховного Суду від 11 грудня 2018 р. у справі №910/8122/17. URL:http://reyestr.court.gov.ua/Review/78977479.

15. Конвенція про доступ до інформації, участь громадськості в процесі прийняття рішень та доступ до правосудпя 3 питань, що стосуються довкілля (Орхуська конвеншія): Ратифікована Законом України№832-XIV (832-14) від06.07.1999 p.URL.https://zakon.rada.gov.ua/laws/show/994_015.

\section{References:}

1. Polozhennia pro hromadskyi kontrol $\mathrm{u}$ haluzi okhorony navkolyshnoho pryrodnoho seredovyshcha: nakaz Minpryrody № 81 vid 04.08.1994 r. (nakaz vtratyv chynnist na pidstavi nakazu Minekobezpeky № 150 vid 05.07.1999 r.). (1999) N. p. URL:https:/ / zakon.rada.gov.ua/laws/show/z022994. [inUkrainian].

2. Malysheva, N. R., Yerofeiev, M. I. (2017) Naukovo-praktychnyi komentar do Zakonu Ukrainy «Pro okhoronu navkolyshnoho pryrodnoho seredovyshcha». Kharkiv: Pravo, 147-149. [in Ukrainian].

3. Berzina, S. V. (2017) Hromadskyi ekolohichnyi kontrol: posib. dlia hromadskykhinspektoriv z okhorony dovkillia / S. V. Berzina, V. Ye. Boreiko, H. S. Buzan (Eds.); I. O. Yakovliev. (Ed.) Kyiv: Instytut ekolohichnoho upravlinnia ta zbalansovanoho pryrodokorystuvannia. [in Ukrainian].

4. Komarnytskyi, V. M., Yerofeiev, M. I. (2017) Politseiske zabezpechennia ekolohichnoi bezpeky: pravovi pytannia//Visnyk Luhanskoho derzhavnoho universytetu vnutrishnikh sprav imeni E. O. Didorenka - Bulletin of Luhansk State University of Internal Affairs named after E. Didorenko, issue 1, 150-157. [in Ukrainian].

5. Kazanchuk, I. D. (2017) Kompetentsiia orhaniv Natsionalnoi politsii Ukrainy shchodo okhorony navkolyshnoho pryrodnoho seredovyshcha ta ekolohichnoi bezpeky v intehratsiinykh umovakh//Nashe prawo - Our right, 1, 54-61. URL:http://nashe-pravo.unesco-socio.in. ua/?s=\% E2\%84\%961+2017. [in Ukrainian]. 
6. Hamaliuk, B. M. (2016) Diialnist Natsionalnoi politsii Ukrainy z dotrymannia derzhavnykh ekolohichnykh harantii: teoretyko-metodolohichnyi aspekt//Zbirnyk naukovykh prats Lvivskoho derzhavnoho universytetu onutrishnikh sprav. Seriia yurydychna - Collection of scientific works of Lviv State University of Internal Affairs. The series is legal, issue 3, 150-161. URL:http://www.lvduvs.edu.ua/seriyaur?limitstart=0). [in Ukrainian].

7. Ovcharenko, O. (2016) "Reforma ekolohichnoi inspektsii povynna vidbutys za modelliu reformy politsii, - Ostap Semerak"/O. Ovcharenko, T. Kukhar (Eds.) Lvivskyi portal: Internet-vydannia. URL:http:/ / portal.lviv.ua/news/2016/05/28/reforma-ekologichnoyi-inspektsiyi-povinnavidbutis-za-modellyu-reformi-politsiyi-ostap-semerak.). [in Ukrainian].

8. Stvorennia ekolohichnoi politsii (ekopolitsii) dlia poperedzhennia ta prypynennia pravoporushen u sferi okhorony dovkillia. Avtor (initsiator): Yalovyi Kostiantyn Volodymyrovych. Data opryliudnennia: 28 kvitnia 2020 r. № 22/094470-ep. (2020) Elektronni petytsii. Ofitsiine Internetpredstavnytstvo Prezydenta Ukrainy. URL:https://petition.president.gov.ua/petition/94470). [in Ukrainian].

9. Yalovyi, K. (2020) Ukraini potribna ekolohichna politsiia. Ukrainska pravda. 27.04.2020 Ukrainian Pravda. 27.04.2020 r. URL:https://www.pravda.com.ua/columns/2020/04/27/7249509. [in Ukrainian].

10. Karnaukh, L. Ekolohichna reforma: yak usunuty koruptsiini ryzyky pry zmini systemy? LexInform. Yurydychni nooyny Ukrainy-LexInform. Legal news of Ukraine. N. d. URL:https:/ / lexinform. com.ua/v-ukraini/ekologichna-reforma-yak-usunuty-koruptsijni-ryzyky-pry-zmini-systemy/. [in Ukrainian].

11. Komarnytskyi, V. M., Yerofeiev, M. I. (2019) Pravovi ta orhanizatsiini aspekty antykoruptsiinoi polityky v haluzi okhorony dovkillia. Osoblyvosti pravovoho rehuliuvannia ekolohichnykh, zemelnykh, ahrarnykh, pryrodoresursnykh vidnosyn v umovakh hlobalizatsii. Zbirnyk materialiv Vseukrainskoi naukovo-praktychnoi konferentsii (m. Ivano-Frankivsk, 20-22 veresnia 2019 r.- Features of legal regulation of ecological, land, agrarian, natural resource relations in the conditions of globalization. Proceedings of the AllUkrainian scientific-practical conference (Ivano-Frankivsk, September 20-22, 2019) Ivano-Frankivsk - m. Yaremche: Prykarpat. nats. un-t im. Vasylia Stefanyka, 70-74. [in Ukrainian].

12. Yerofeiev, M. I. (2020) Kryminalna vidpovidalnist za pravoporushennia u sferi otsinky vplyvu na dovkillia: pytannia udoskonalennia zakonodavchoho rehuliuvannia/ / Visnyk Luhanskoho derzhavnoho universytetu vnutrishnikh sprav imeni E. O. Didorenka-Bulletin of Luhansk State University of Internal Affairs named after E. Didorenko, issue 1 (89), 71-79. [in Ukrainian].

13. Rishennia Konstytutsiinoho Sudu Ukrainy u spravi za konstytutsiinym zvernenniam hromadianky Dziuby Halyny Pavlivny shchodo ofitsiinoho tlumachennia chastyny druhoi statti 55 Konstytutsii Ukrainy ta statti 248-2 Tsyvilnoho protsesualnoho kodeksu Ukrainy (sprava hromadianky Dziuby H. P. shchodo prava na oskarzhennia v sudi nepravomirnykh dii posadovoi osoby) vid 25.11.1997 r. (1997) N. p. URL:https:/ /zakon.rada.gov.ua/laws/show/v006p710-97. [in Ukrainian].

14. Postanova Velykoi Palaty Verkhovnoho Sudu vid 11 hrudnia 2018 r. u spravi № 910/8122/17. (2018) N. p. URL:http:/ / reyestr.court.gov.ua/Review/78977479. [in Ukrainian].

15. Konventsiia pro dostup do informatsii, uchast hromadskosti $v$ protsesi pryiniattia rishen ta dostup do pravosuddia z pytan, shcho stosuiutsia dovkillia (Orkhuska konventsiia): Ratyfikovana Zakonom Ukrainy № 832-XIV(832-14) vid 06.07.1999 r. (1999) N. p. URL:https://zakon.rada.gov. ua/laws/show/994_015. [in Ukrainian]. 
Комарнищкий В. М., доктор юридических наук, профессор, ведущий научный сотрудник научно-исследовательской лаборатории по проблемам предупреждения, прекращения и расследования преступлений территориальными органами Национальной полиции Украины Луганского государственного университета внутренних дел имени Э. А. Дидоренко

(г. Северодонецк, Украина)

Ерофеев Н. И.,

кандидат юридических наук, научный сотрудник научно-исследовательской лаборатории по проблемам предупреждения, прекращения и расследования преступлений территориальными органами Национальной полищии Украины Луганского государственного университета внутренних дел имени Э. А. Дидоренко

(г. Северодонецк, Украина)

\section{ПРАВОВЫЕ ВОПРОСЫ ВЗАИМОДЕЙСТВИЯ ПРАВООХРАНИТЕЛЬНЫХ ОРГАНОВ С ОБЩЕСТВЕННОСТЬЮ ПО ОБЕСПЕЧЕНИЮ ОХРАНЫ ОКРУЖАЮЩЕЙ СРЕДЫ}

В статье рассмотрены проблемы прав граждан, общественных объединений в сфере охраны окружающей среды; основные формы реализации этих прав в процессе взаимодействия 3 правоохранительными органами. Акцентировано внимание на недочетах законодательства в регулировании отношений, возникающих между общественностью и правоохранительными органами при осуществлении екологического контроля, привлечении к юридической ответственности нарушителей екологического законодательства, судебной защиты екологических интересов общества. Также обоснованы рекомендации и даны предложения по устранению этих недочетов.

Ключевые слова: общественность, правоохранительные органы, взаимодействие, охрана окружающей среды, экологическое законодательство.

Komarnytskyi V.,

Doctor of Law, Professor, Leading Researcher at the Luhansk State University of Internal Affairs named after E. Didorenko Research Laboratory on Crime Prevention, Termination and Investigation

by Territorial Authorities of the National Police of Ukraine (Sievierodonetsk, Ukraine)

Yerofeiev M.

Candidate of Law Sciences, Researcher at the Luhansk State University of Internal Affairs named after E. Didorenko Research Laboratory on Crime Prevention, Termination and Investigation by Territorial Authorities of the National Police of Ukraine (Sievierodonetsk, Ukraine)

\section{LEGAL ISSUES OF INTERACTION OF LAW ENFORCEMENT AGENCIES WITH THE PUBLIC TO ENSURE ENVIRONMENTAL PROTECTION}

The article considers the rights of citizens, public associations in the field of environmental protection, the main forms of realization of these rights in the process of interaction with law 
enforcement agencies. Emphasis is placed on the shortcomings of the legislation in regulating relations between the public and law enforcement agencies in the implementation of environmental control, prosecution of violators of environmental legislation, judicial protection of environmental interests of society, as well as sound recommendations and proposals to address these legislative gaps and shortcomings.

In particular, the expediency of granting the right to establish public environmental inspections by public environmental associations has been proved. This would give the latter more independence in the organization of inspections of compliance with environmental legislation and greater opportunities to influence the activities (inaction) of government agencies in this area. Such a right of public environmental associations should be provided in Art. 36 of the Law of Ukraine "On Environmental Protection". Also, according to the authors, this Law (Article 9 and paragraph "zh" of the first part of Article 21) should be supplemented with provisions that give citizens and public environmental associations the right to file a lawsuit to terminate their activities which harms the environment. This will eliminate the gap in the definition of environmental rights of citizens and public environmental associations in the Law of Ukraine "On Environmental Protection", will improve the legal framework for public interaction with the judiciary in addressing relevant issues.

The authors believe that the Law of Ukraine "On Environmental Protection" should reflect the real environmental practice of the police based on interaction with relevant institutions of civil society. To this end, it (Article 21) should provide for a provision according to which public environmental associations will have the right to take measures together with the police to prevent and stop administrative offenses and environmental crimes.The article also emphasizes the importance of combining the forces and capabilities of various public formations, including those operating under the auspices of law enforcement agencies (public formations for the protection of public order and the state border) to enhance the effectiveness of environmental activities in Ukraine. This point should also be taken into account in the Law of Ukraine "On Environmental Protection" (Article 21), which should fix the right of public environmental associations to organize interaction with other public groups in the implementation of measures to combat environmental offenses.

Focusing on legal liability, the authors argue the need to separate in the Criminal Code of Ukraine a separate article on crimes in the field of environmental impact assessment, and the inclusion in the list of corruption crimes in the field of environmental impact assessment under Article 15 of the Law of Ukraine "On environmental impact assessment", which can be committed only by abuse of office (failure to take into account in the prescribed manner the results of environmental impact assessment when deciding on the planned activities; preparation of a knowingly false conclusion on environmental impact assessment). The article emphasizes that for the public to establish in the Criminal Code of Ukraine the composition of crimes in the field of environmental impact assessment with clear qualifying features, it is important that it receives specific guidelines for determining (verifying) compliance with the actions of entities involved in environmental impact assessment, the requirements of the legislation governing implementation.

The authors support the proposals on the establishment of the Environmental Police in Ukraine, believing that in this case the public will get a powerful partner in the fight against environmental offenses.

Keywords: public, law enforcement bodies, interaction, environmental protection, ecological legislation. 